University of Nebraska - Lincoln

DigitalCommons@University of Nebraska - Lincoln

USDA National Wildlife Research Center - Staff Publications
U.S. Department of Agriculture: Animal and Plant Health Inspection Service

January 2005

\title{
The Use of Culmen Length to Determine Sex of the American White Pelican
}

Brian S. Dorr

USDA-APHIS-Wildlife Services, brian.s.dorr@aphis.usda.gov

D. Tommy King

U.S. Fish and Wildlife Service, tommy.king@aphis.usda.gov

Patrick Gerard

Mississippi State University, pdg1@ra.msstate.edu

Marilyn G. Spalding

University of Florida, rosie@nersp.nerdc.ufl.edu

Follow this and additional works at: https://digitalcommons.unl.edu/icwdm_usdanwrc

Part of the Environmental Sciences Commons

Dorr, Brian S.; King, D. Tommy; Gerard, Patrick; and Spalding, Marilyn G., "The Use of Culmen Length to Determine Sex of the American White Pelican" (2005). USDA National Wildlife Research Center - Staff Publications. 9.

https://digitalcommons.unl.edu/icwdm_usdanwrc/9

This Article is brought to you for free and open access by the U.S. Department of Agriculture: Animal and Plant Health Inspection Service at DigitalCommons@University of Nebraska - Lincoln. It has been accepted for inclusion in USDA National Wildlife Research Center - Staff Publications by an authorized administrator of DigitalCommons@University of Nebraska - Lincoln. 


\title{
The Use of Culmen Length to Determine Sex of the American White Pelican
}

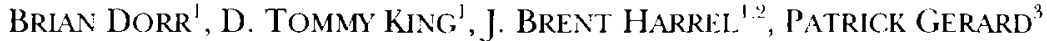 \\ AND MaRILIN G. SPALDiNG \\ 'L.S. Department of Agriculture, Animal Plant Health Inspection Service, Wildlife Services \\ National Wildlife Research Center, P.O. Drawer 6099, Mississippi State, MS 39762-6099, USA \\ Internet: brian.s.doriaphis.usda.gov
}

${ }^{2}$ Present address: U.S. Fish and Wildlife Service, Kentucky Field Office 3761 Georgetown Road, Frankfort, KY 40601, USA

${ }^{3}$ Mississippi State University, Experimental Statistics Unit I51 Dorman Hall, Mississippi Stale, MS 39762, L'SA

${ }^{4}$ University of Florida, College of Veterinary Medicine, Department of Pathobiology Box 110880 , Gainesville, FL 32610, USA

\begin{abstract}
Culmen length has been suggested as being diagnostic for sex in the American White Pelicans (Pelecanus anthrorhynchos). However, the literature on the use of culmen length to determine sex is inconsistent, with reported overlap in culmen lengths for males and females ranging from $1 \mathrm{~mm}$ to $>120 \mathrm{~mm}$. Morphological measurements from 188 Arnerican White Pelicans collected in Mississippi and Louisiana whose sex was determined by dissection and gonadal inspection were measured. The use of culmen length alone was used to determine gender for this sample by establishing the minimum observed culmen length for tilales and the maximum observed culmen length for females that provided the fewest incorrect determinations for each gender. A multivariate discriminant function model was developed to determine sex from our data and compared the diagnostic accuracy of the model with the accuracy based on culmen length alone. Both methods were validated using an independently collected sample of 22 pelicans from Florida. A culmen length of $\geq 310 \mathrm{~nm}$ for males and $\leq 309 \mathrm{~mm}$ for females fronı our data correctly classified sex for $99 \%$ of American White Pelicans from our Mississippi and Louisiana samples and $95 \%$ of AWPE for the Florida sample. Culmen length and wingcord length were significant variables in the discrininant function model. The resulting model correctly classified sex of $97 \%$ of the birds and $94 \%$ of the independent Florida sample. The culmen length alone predicted the sex of American White Pelicans as well as multivariate methods and provides an accurate simple, non-lethal method for sexing the species.
\end{abstract}

Key words.-gender, discriminant analysis, morphometrics, American White Pelican.

Waterbirds 28 (Special Publication 1): 102-106, 2005

The ability to identify the sex of individual birds under study in sexually monochromatic species, such as the American White Pelican (Pelecanus erythrorhynchos) is often of interest to researchers. Relatively easy, nonlethal techniques to identify sex are useful for studying aspects of avian biology including foraging ecology, behavior, evolutionary and conservation genetics, survivorship and dispersion (Anderson and Norberg 1981; Clutton-Brock 1986; Newton et al. 1983; Griffith and Tawari 1995).

The American White Pelican (AWPE) has been described as being sexually dimorphic with respect to culmen length, weight, wingcord and cloacal characteristics (Bent 1964; Palmer 1962; Lingle and Sloan 1979). However, differing cloacal characteristics have only been determined soon after breeding occurs and does not include pre-breeding birds (Lingle and Sloan 1979). Additionally, considerable overlap in most of these measurements suggests that univariate techniques to sex AWPE may be inaccurate. A univariate measure that may serve to distinguish gender is culmen length. Palmer (1962) reported that male $(\mathrm{N}=9)$ culmen lengths are $\geq 320$ $\mathrm{mm}$ and female $(\mathrm{N}=10)$ culmen lengths are $\leq 320 \mathrm{~mm}$ ( $1 \mathrm{~mm}$ overlap). However, Lingle and Sloan (1979) reported a much greater overlap $(\sim 120 \mathrm{~mm})$ in adult AWPE $(\mathrm{N}=47)$, and Lingle and Sloan (1979) indicated that only males $(N=26)$ with culmen lengths $\geq 345$ $\mathrm{mm}$ and females $(\mathrm{N}=21)$ of $\leq 245 \mathrm{~mm}$ (i.e., at least a $100 \mathrm{~mm}$ difference) could be accurately $(\mathrm{P}<0.05)$ sexed. 
Multivariate approaches such as discriminant analyses (DA) of external measurcments have been used 10 distinguish sex of birds and often has proved to be of greater accuracy than univariate methods. This method has been used to determine sex of other Pelecaniformes such as the King Colmorant (Phalacrocorax atriceps albiuenter) and Double-crested Cormorant (Phalacrocorax auritus) (Malacalaza and Hall 1988; Bedard et al. 1995; Glahn and McCoy 1995). This technique has been utilized for many other monochromatic species (Blemilan el al. 1984; Clark et al. 1991; Fox et al. 1981; Hanners and Patton 1985; Haywood and Haywood 1991; Maron and Myers 1984; McCloskey and Thompson 2000). The objectives of this study were to: (1) clarify inconsistencies in the published literature on the use of culmen length to sex AWPE, (2) evaluate the accuracy of culmen length to sex AWPE versus a multivariate model and (3) develop an accurate and non-lethal field technique to sex these birds.

\section{METHODS}

From April 1998 to April 1999, AWPE were collected from eight locations in the delta region of Mississippi and in coastal regions and inland areas along the Atchafalaya River basin in Louisiana. Three linear measurements were selected that would be repeatable, had been shown to provide a minimum of measurement error in other bird species and had been suggested by previous research as being diagnostic for sex (Palmer 1964; Lingle and Sloan 1979; Lougheed et al. 1991). Measurements were taken on all birds for culmen length (straight line down the center of the bill from most distal point to the feathered edge at the base), (flattened) wing cord (wrist joint to the tip of the longest primary) and tarsal length (metatarsus measured from proximal to distal joint). In addition to these measurements, body mass of each individual was recorded. Measurements for culmen and wingcord were taken to the nearest millimeter using a stopped metric ruler. A vernier caliper was used to measure tarsus length to the nearest 0.1 $\mathrm{mm}$. Body mass was measured to the nearest $0.2 \mathrm{~kg}$ with a $20 \mathrm{~kg}$ Pesola spring scale and sex was determined from dissection and gonadal inspection. Age (adult, subadult or juvenile) was determined from plumage based on characteristics described by Lingle and Sloan (1979) and Evans and Knopf (1993).

Equality of group means between sexes was investigated by performing a test on each of the variables considered (SAS Insititute 1994). The use of culmen length alone was evaluationed for determining gender by establishing the minimum observed culmen length for males and the maximum observed culmen length for females that provided the fewest incorrect determi- nations for each gender. These values were then qualitatively evaluated against an independently collected sample from Florida.

Determination of gender was evaluated to determine if accuracy could be improved by inclusion of additional morphological metrics. We used stepwise DA (PROC STEPDISC; SAS Insititute 1994; SAS Insititute 1996) to select (criteria $P \leq 0.10$ ) variables for the model (Costanza and Affii 1979). The resulting model was tested by cross-ralidation methods to estimate accuracy (SAS lusititute 1994).

The applicability of field measure to determine gender is best evaluated against independently collected samples. Additionally, discriminant function models often fit the sample from which they were derived beller than they fit other samples, possibly resulting in inflation of the true performance of the model (Norusis 1988; SAS Insititute 1994). Therefore, an independent sample of AWPE collected in Florida was used to validate the accuracy of each of the methods (i.e., DA vs. culmen length). The performance of each method in determining gender were then qualitatively compared.

The birds from the Florida sample were collected freshly dead or moribund from Orange, Marion, Brevard, Columbia, Dade, Lake, Monroe, Volusia and Wakulla Counties from 8 January to 5 April 1999 and 2628 January 2000. Measurements taken were similar to our data except the wing cord for this sample was not flattened. In addition to validation of methods developed from our data, the independent sample provided a measure of the rcgional applicability of the methods evaluated and robustness with respect to measurements taken by different observers.

\section{RESULTS}

A total of 198 AWPE were collected at ten locations in Mississippi and Louisiana. Of these, 188 were suitable for use in the resulting discriminant function model (i.e., they did not have gross indications of disease, or injury that precluded their use in the model). Of these, 160 were male and 28 were female. For males, 73 were classified as adult and 87 as subadult. For females, 18 were classified as adult and 10 as subadult. Means for all measurements were significantly larger for males than for females; however, there was overlap for all categories including culmen length (Table 1). The minimum culmen length recorded for males was $287 \mathrm{~mm}$ and the maximum recorded for females was $360 \mathrm{~mm}$.

There were 28 pelicans in the Florida validation sample, 22 of which had the required information for validation of the discriminant function model and culmen length. Of these, nine were female and 13 were male. For males, five were classified as adult, two as first year birds and six as subadult. For fe- 
Table 1. Mean, standard error (SE), range, $t$-value $(t)$ and probability $(P)$ of a larger morphometric measurements of male and female American White Pelicans collected in Mississippi and Louisiana, April 1998-April 1999, based on 160 males and 28 females.

\begin{tabular}{|c|c|c|c|c|}
\hline Measurements & $\begin{array}{c}\text { Males } \\
\text { mean } \pm \mathrm{SE} \\
\text { (range) }\end{array}$ & $\begin{array}{c}\text { Females } \\
\text { mean } \pm \mathrm{SE} \\
\text { (range) }\end{array}$ & $t$ & $P$ \\
\hline Body mass (g) & $\begin{array}{l}6,486 \pm 530 \\
(5,000-8,000)\end{array}$ & $\begin{array}{l}5,154 \pm 129 \\
(4,200-6,200)\end{array}$ & 9.6 & $<0.0001$ \\
\hline Wing cord ( $\mathrm{mm})$ & $\begin{array}{l}606.0 \pm 1.6 \\
(541-675)\end{array}$ & $\begin{array}{l}560.0 \pm 4.7 \\
(511-598)\end{array}$ & 10.9 & $<0.0001$ \\
\hline Culmen length & $\begin{array}{l}349.0 \pm 1.2 \\
(287-385)\end{array}$ & $\begin{array}{l}283.0 \pm 2.3 \\
(260-360)\end{array}$ & 21.7 & $<0.0001$ \\
\hline Tarsal length & $\begin{array}{l}120.4 \pm 0.4 \\
(105-137)\end{array}$ & $\begin{array}{l}111.0 \pm 1.2 \\
(100-120)\end{array}$ & 8.1 & $<0.000 \mathrm{I}$ \\
\hline
\end{tabular}

males, four were classified as adult and five in their first year. Means for all measurements except tarsus length were significantly larger for males than for females. As in our sample, there was overlap for all categories of measurements including culmen length. (Table 2). The minimum value recorded for males was $345 \mathrm{~mm}$ and the maximum for females was $356 \mathrm{~mm}$.

Qualitative analysis of the data indicated a minimum culmen length for males of 310 $\mathrm{mm}$ and a maximum culmen length for females of $305 \mathrm{~mm}$, provided the minimum number of incorrect gender classifications. Because we had a larger sample-size for males than females we used a value of $\geq 310$ $\mathrm{mm}$ for males and $\leq 309 \mathrm{~mm}$ for females for evaluating the independently-collected Florida sample. Based on these criteria, culmen length alone correctly classified sex for $98 \%$
$(\mathrm{N}=188)$ AWPE for our data and $95 \%(\mathrm{~N}=$ 22) of pelicans for the Florida sample. Only two birds were misclassified from our data, one male with a culmen length of $287 \mathrm{~mm}$, and one female with a culmen length of 360 $\mathrm{mm}$. Only one observation was misclassified for the Florida sample, a female with a culmen length of $356 \mathrm{~mm}$.

The stepwise selection procedure selected only culmen length and wingcord length as significant variables in the discriminant function model (Table 3). Within model cross-validation correctly predicted females in $96 \%(\mathrm{~N}=28)$ of the samples and for males in $97 \%(\mathrm{~N}=160)$ of the samples. Overall prediction for both sexes was correct for $97 \%$ of AWPE. The independent sample cross-validation correctly predicted females in $89 \%$ $(\mathrm{N}=9)$ of the samples and for males in $100 \%$ $(\mathrm{N}=11)$ of the samples.

Table 2. Mean $(\overline{\mathbf{x}})$, standard error $(\mathrm{SE})$, range, $t$-value $(t)$ and probability $(P)$ of a greater $t$ for morphometric measurements of 13 male and 9 female American White Pelicans collected in Florida, 8 January, 5 April 1999 and 26-28 January 2000 and used for validation purposes. The notation (n.s.) means not significant at $P \leq 0.05$.

\begin{tabular}{|c|c|c|c|c|}
\hline Measurements & $\begin{array}{c}\text { Males } \\
\overline{\mathrm{x}} \pm \mathrm{SE} \\
\text { (range) }\end{array}$ & $\begin{array}{c}\text { Females } \\
\overline{\mathrm{x}} \pm \mathrm{SE} \\
\text { (range) }\end{array}$ & $\mathrm{t}$ & $\mathbf{P}$ \\
\hline Body mass (g) & $\begin{array}{l}5,451 \pm 173 \\
(4,600-6,250)\end{array}$ & $\begin{array}{l}4,124 \pm 278 \\
(3,327-5,780)\end{array}$ & 4.05 & $<0.001$ \\
\hline Wing cord $(\mathrm{mm})$ & $\begin{array}{l}576.0 \pm 6.8 \\
(543-620)\end{array}$ & $\begin{array}{l}506.0 \pm 24.4 \\
(320-570)\end{array}$ & 2.74 & $<0.02$ \\
\hline Culmen length & $\begin{array}{l}359.0 \pm 3.0 \\
(345-380)\end{array}$ & $\begin{array}{l}298.0 \pm 7.5 \\
(280-356)\end{array}$ & 7.53 & $<0.001$ \\
\hline Tarsal length & $\begin{array}{l}118.0 \pm 2.4 \\
(100-136)\end{array}$ & $\begin{array}{l}114.0 \pm 2.6 \\
(103-128)\end{array}$ & 1.07 & n.s. \\
\hline
\end{tabular}


Table 3. Stepwise analysis of morphometric measurements of 160 male and 28 female American White Pelicans collected in Mississippi and Louisiana, April 1998-April 1999. The notation (n.s.) means not significant.

\begin{tabular}{|c|c|c|c|c|}
\hline Step & Variable entered & Patrial $\mathrm{R}^{2}$ & F-value & $\mathrm{p}$ \\
\hline 1 & Culmen (mm) & 0.66 & 359.70 & $<0.000 \mathrm{l}$ \\
\hline 2 & Wing cold (mm) & 0.08 & 15.80 & $<0.0001$ \\
\hline 3 & Mass (kg) & $<0.01$ & 0.39 & n.s. \\
\hline 4 & Tarsus (mm) & $<0.01$ & 0.58 & n.s. \\
\hline
\end{tabular}

\section{DISCUSSION}

Overlap and ranges of culmen lengths for both our sample and the sample collected from Florida were within the range of values previously reported (Palmer 1962; Lingle and Sloan 1979). However, overlap with respect to culmen length was represented by only two individuals (one male and one female) from our sample population and one female from the Florida sample. Unlike Lingle and Sloan (1979) who reported considerable overlap in culmen length between sexes, our results concur with those of Palmer (1962) whose data suggested that AWPE could be accurately sexed using culmen length alone. Moreover, the addition of other morphological metrics in a discriminant function model did not provide greater accuracy in gender determination. Thus a culmen length of $\geq 310 \mathrm{~mm}$ for males and $\leq 309 \mathrm{~mm}$ for females provides an accurate simple, non-lethal method for determining gender of AWPE.

Unlike research conducted on the Double-crested Cormorant (Glahn and McCoy 1995), there were no regional differences in morphometric characteristics between samples collected in Mississippi and Louisiana or Florida. Although, the overall percentage of samples correctly classified for the independently collected Florida sample was lower than for our sample, a small sample-size for females $(\mathrm{N}=9)$ from the independent sample may have inflated the error estimate.

The use of culmen length for gender determination of the AWPE should be useful to researchers and biologists. The field method is rapid, easy and unobtrusive compared to techniques such as laparotomy or molecular methods (Ellegren 1996; Balbontin et al. 2001). Although, Lingle and Sloan (1979) developed useful field techniques to identify the gender of adult AWPE soon after breeding, the use of culmen length provides a method for doing this on AWPE year-round throughout their life. Additionally, the culmen would likely degrade more slowly than internal organs, so it may be useful for identifying the sex of AWPE carcasses.

The use of culmen length to determine sex appears to be applicable to AWPE. ranging from Louisiana to Florida. However, we have no information on the applicability of this measure to AWPE from elsewhere in their range (such as west of the Rocky Mountains). We encourage researchers to verify this method with individuals collected outside the regions encompassed in this study.

\section{ACKNOWLIEDMENTS}

We thank Dwight LeBlanc and his staff with Louisiana Wildlife Services; Bo Sloan, Greg Ellis and staff with Mississippi Wildlife Services; and staff with the Louisiana Department of Wildlife and Fisheries for their help with access, collections and processing of specimens. We thank catfish producers in Louisiana and Misssissippi for helping with collections and allowing us access to their facilities. We also thank S. Werner, M. Tobin and J. Jones for their reviews of this manuscript.

\section{LITHRATURE CITED}

Anderson, M. and R. A. Norberg. 1981. Evolution of reversed sexual size dimorphism and role partitioning among predatory birds, with size scaling of flight performance. Biological Journal of the Linnean Society 15: 105-130.

Balbontin, J., M. Ferrer and E. Casado. 2001. Sex determination in Booted Eagles (Hiercuatus pennatus) using molecular procedures and discriminant function analysis. Journal of Raptor Research 35: 20-23.

Bedard, J., A. Nadeau and M. Lepage. 1995. Doublecrested Comorant morphometry and field sexing in the St. Lawrence River estuary. Colonial Waterbirds 18 (Special Publication 1): 86-90.

Bent, A. C. 1964. Life histories of North American petrels and pelicans and their allies. Dover Publishing, lıc., New York. 
Brennan, L. A., J. B. Buchanan, C. T. Schick, S. G. Herman and T. M. Johnson. 1984. Sex detemination of Dunlins in winter plumage. Joumal of Field Ornithology 55: 343-348.

Clark, R. G., P. C. James and I. B. Morali. 1991. Sexing adult and vearling American Ciows by external measurements and discriminant analysis. Journal of Field Onithology 62: 132-138.

Cluton-Brock. T. H. 1986. Sex ratio variation in birds. Ibis 128: $317-329$.

Costanza, M. C. and A. A. Afifi. 1979. Comparison of stopping rules in forward stepwise discriminant analysis. Journal of the American Statistical Association 74: 777-785.

Ellegren, H. 1996. First gene on the avian W chromosome (CHD) provides a tag for universal sexing of non-ratite birds. Proceedings of the Royal Society of London 263: 1635-1641.

Evans, R. M. and F. L. Knopf. 1993. American White Pelican (Pelecanus erythromynchos). No. 57 in A. Poole and F. Gill (Eds.), The Birds of North Anerica. The Academy of Natural Sciences, Philadelphia, and The American Onnithologists' Union, Washington, DC.

Fox, G. A., C. R. Cooper and J. P'. Ryder. 1981. Predicting the sex of Herring Gulls by using external measurements. Journal of Ficld Ornithology 52: 1-9.

Glahn, J. F. and R. B. McCoy. 1995. Measurement of wintering Doublecrested Cormorants and discriminant models of sex. Journal of Field Ornithology 66: 299-304.

Griffith, R. and B. Tiwari. 1995. Sex of the last wild Spix's Macaw. Nature (London): 375-454.

Hanners, L. A. and S. R. Patton. 1985. Sexing Laughing Gulls using external measurements and discrininant analysis. Journal of Field Ornithology 56: 158-164.
Hawrood, G. D. and P. H. Hawwood. 1991. Bodv measurements of Boreal Owls in Idaho and a discrimi nant model to determine sex of live specimens. Wilson Bulletin 103: 497-500

Lingle, G. R. and N. F. Sloan. 1979. Sexing and ageing criteria for the White Pelican. Prairie Naturalist 11: 83-88.

Lougheed, S. C., T. W. Amold and R. C. Bailev: 1991 Measurement error for external and skeletal vari ables in birds and its effect on principal components. Auk 108: 432-436.

Malacalaza, V. F. and M. A. Hall. 1988. Sexing adult King Cormorants (Phalacrocorax alliventer) by cliscriminant analysis. Colonial Waterbirds 11: 32-37.

Maron, J. L. and J. P. Myers. 1984. A description and evaluation of two techniques for sexing wintering sanderlings. Journal of Field Ornithology 55: 336 337.

McCloskey, J. T. and J. E. Thompson. 2000. Ageing and sexing Common Snipe using discriminant analysis. Journal of Wildlife Management 64: 960 969.

Newton, I., M. Marquiss and P. Rothery, 1983. Age structure and survival in a Sparrowhawk population.Joulnal of Animal Ecology 52: 591-602.

Norusis M. J. I988. SPSS/PC+ advanced statistics V2.0 SPSS, Chicago.

Palmer, R. (Ed.). 1962. Handbook of North American birds: Volume 1, loons through flamingos. Yale University Press, New Haven, Connecticut.

SAS Insititute. 1994. SAS/STAT user's guide. SAS Institute, Cary, North Carolina.

SAS Insititute. 1996. SAS/STAT changes and enhancements. SAS Institute, Cary, North Carolina. 